\title{
Preoperative workup, patient selection, surgical technique and follow-up for a successful laparoscopic Nissen fundoplication
}

\author{
Rafael Melillo Laurino Neto, Fernando A. M. Herbella \\ Department of Surgery, Escola Paulista de Medicina, Federal University of Sao Paulo, Sao Paulo 04037-003, Brazil.
}

Correspondence to: Dr. Fernando A. M. Herbella, Department of Surgery, Escola Paulista de Medicina, Federal University of Sao Paulo, Rua Diogo de Faria 1087 cj 301, Sao Paulo 04037-003, Brazil. E-mail: herbella.dcir@epm.br

How to cite this article: Neto RML, Herbella FAM. Preoperative workup, patient selection, surgical technique and follow-up for a successful laparoscopic Nissen fundoplication. Mini-invasive Surg 2017;1:6-11.

Article history:

Received: 02-10-2016

Accepted: 14-12-2016

Published: 31-03-2017

Key words:

Gastroesophageal reflux disease,

surgery,

fundoplication,

outcomes

\begin{abstract}
Experienced surgeons have reported excellent results for laparoscopic Nissen fundoplication to treat gastroesophageal reflux disease (GERD). Others, however, associate this operation with unacceptable rates of morbidity, mortality and inferior outcomes. Results are certainly linked to an appropriate patient selection, work up, technical details and follow-up. This review focuses on the proper preoperative workup, patient selection, surgical technique, and followup for a successful laparoscopic Nissen fundoplication. Certainty of the diagnosis of GERD and the esophageal physiology is essential. An extensive dissection of the esophagus and crus in the abdomen and mediastinum, an adequate hiatoplasty, and a short-floppy fundoplication are important technical points. New onset or persistent symptoms after the operation must be carefully studied. Excellent outcomes may be reproducible if a proper preoperative workup, patient selection, surgical technique and follow-up are rigorously observed.
\end{abstract}

\section{INTRODUCTION}

Some experienced surgeons have reported good and excellent results in more than $90 \%$ of patients submitted to laparoscopic Nissen fundoplication for gastroesophageal reflux disease (GERD). $\cdot^{[1-4]}$ Others, however, associate this operation to unacceptable rates of morbidity, mortality and inferior outcomes. ${ }^{[5]}$ Results are certainly linked to an appropriate patient selection, work up, ${ }^{[6]}$ technical details ${ }^{[7]}$ and follow-up. ${ }^{\left[{ }^{[8]}\right.}$

This paper focuses on the proper preoperative workup, patient selection, surgical technique and follow-up for a successful laparoscopic Nissen fundoplication.

\section{WORKUP}

An extensive esophageal work up with endoscopy, barium esophagraphy, manometry and $\mathrm{pH}$ monitoring is mandatory before an antireflux operation..$^{[9,10]}$

First of all, outcomes will be excellent if GERD is actually present. Thus, the certainty of the correct diagnosis is required. Although the diagnosis may be easy to perform in patients with typical symptoms and evident alterations in endoscopy as well as $\mathrm{pH}$ monitoring, this task may be more difficult in those with extra esophageal symptoms and normal tests. This is true due to the fact that these tests have a significant

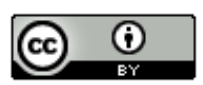

This is an open access article licensed under the terms of Creative Commons Attribution 4.0 International License (https://creativecommons.org/licenses/by/4.0/), which permits unrestricted use, distribution, and reproduction in any medium, as long as the original author is credited and the new creations are licensed under the identical terms.

For reprints contact: service@oaepublish.com

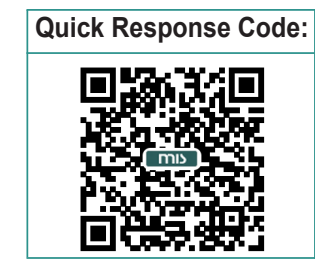


rate of false-negativity.

Many studies have shown that even typical symptoms such as heartburn and regurgitation have low accuracy leading to an incorrect diagnosis of GERD in $30-50 \%$ of patients. ${ }^{[11,12]}$ Likewise, the presence of reflux or hiatal hernia on esophagogram does not correlate well with reflux on $\mathrm{pH}$ monitoring, or esophagitis on endoscopy. ${ }^{[10]}$

Extra esophageal symptoms may bring additional difficulty for the diagnosis. Other tests, such as laryngoscopy may be added to the armamentarium; however, a low positive predictive value for the diagnosis of GERD is anticipated. ${ }^{[13]}$ Other diseases may coexist with GERD. and symptoms may have other causes or may be multifactorial with GERD as only an adjuvant. The response to specific GERD treatment as a trial, and the association of the symptom with reflux episodes at the time of $\mathrm{pH}$ monitoring may help to determine the cause of the symptom.

Ambulatory 24-h pH monitoring should be routinely performed in the preoperative workup of patients suspect of having GERD. ${ }^{[10]}$ Either alone or in combination with multichannel intraluminal impedance (MII-pH) pH monitoring. This testing provides the best objective information on esophageal acid exposure, allowing diagnosing and quantifying GERD, and temporal correlation between symptoms and episodes of reflux. ${ }^{[14]}$

Lastly, an adequate preoperative workup should bring several pieces of information in order to allow a clinical judgement for a better diagnosis since diagnostic tests individually (laryngoscopy, endoscopy, and even $\mathrm{pH}$ or $\mathrm{pH}$-impedance monitoring) may not be sufficient to make the definitive diagnosis of GERD. ${ }^{[15]}$

\section{PATIENT SELECTION}

Following the example of any other elective surgical procedure, patients planned to undergo an antireflux operation should be carefully clinically evaluated. Patients under high anesthetic risk or those with uncontrolled co-morbidities should not be offered this kind of therapy.

Some predictors of worse outcomes after a fundoplication have been identified [Table 1]. Some are inherent to the patient, others to the disease, and some to technical difficulty during the operation. ${ }^{[16-19]}$ With the exception of obesity, these predictors cannot be changed in the majority of patients.

The certainty of the GERD diagnosis and attribution of the symptoms to the disease increase the likelihood of excellent outcomes. Thus, a pathologic $\mathrm{pH}$ monitoring increases the chance of success by 5 times compared to a normal test, ${ }^{[20]}$ and clinical response to acid suppression therapy has been associated with a 3 times better response to surgical treatment. ${ }^{[20]}$ Esophageal symptoms are more prone to be caused by GERD, and also have a better prognosis compared to extra-esophageal symptoms. ${ }^{[18,20]}$

"Illness behavior" may influence ${ }^{[19-21]}$ expectations, satisfaction and tolerance to post-operative side effects.

This fact may explain worse outcomes in females, patients with psychiatric disorders, and individuals of lower socioeconomic status.

Although not unanimously, some series show poorer outcomes for obese patients ${ }^{[18,22]}$ that undergo a fundoplication likely due to a more demanding operation with longer operative times ${ }^{[23]}$ and more complications. ${ }^{[24]}$

One must consider the operation contraindicated in the presence of various predictors for unsuccessful outcomes, while older age and esophageal dysmotility (excluding achalasia) do not influence outcomes. ${ }^{[25,26]}$

\section{TECHNIQUE}

Some technical points must be followed to ensure an adequate fundoplication.

An extensive esophageal dissection in the abdominal and lower thoracic segments to achieve a $2-4 \mathrm{~cm}$ segment of abdominal esophagus is helpful to prevent hernia recurrence. The presence of a long abdominal esophagus is per se an efficient antireflux mechanism [Figure 1],[27] and careful attention should be taken to avoid damage to the vagal branches that are close to this portion of the esophagus. ${ }^{[16,28]}$

Hiatal closure is an important part of this operation since the integrity of this muscle barrier exerts synergistic

Table 1: Predictors for bad outcomes after laparoscopic Nissen fundoplication

\begin{tabular}{lcc}
\hline Patient & Disease & More difficult operation \\
\hline Female gender & $\begin{array}{c}\text { Extra-esophageal } \\
\text { symptoms } \\
\text { Lack of response }\end{array}$ & Obesity \\
$\begin{array}{l}\text { Psychiatric } \\
\text { disorders }\end{array}$ & $\begin{array}{c}\text { Lacid suppression } \\
\text { therapy }\end{array}$ & \\
$\begin{array}{l}\text { Low socioeconomic } \\
\text { status }\end{array}$ & $\begin{array}{c}\text { Absence of hiatal } \\
\text { hernia }\end{array}$ & \\
\hline
\end{tabular}




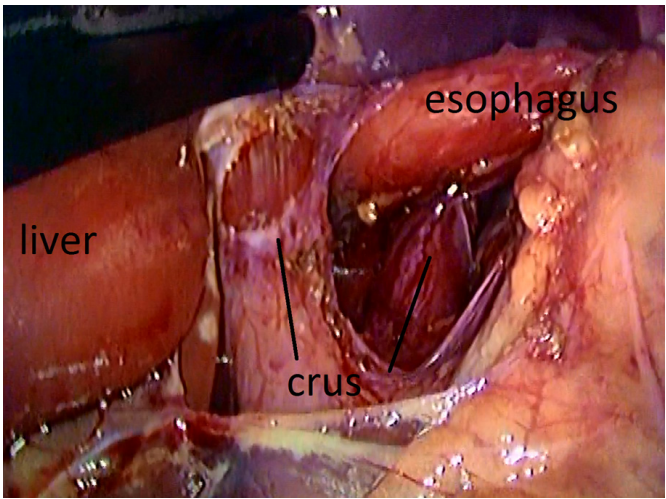

Figure 1: Extensive dissection of the esophagus including the lower mediastinum ensures a long segment of the abdominal esophagus (ideal $>2.5 \mathrm{~cm}$ )

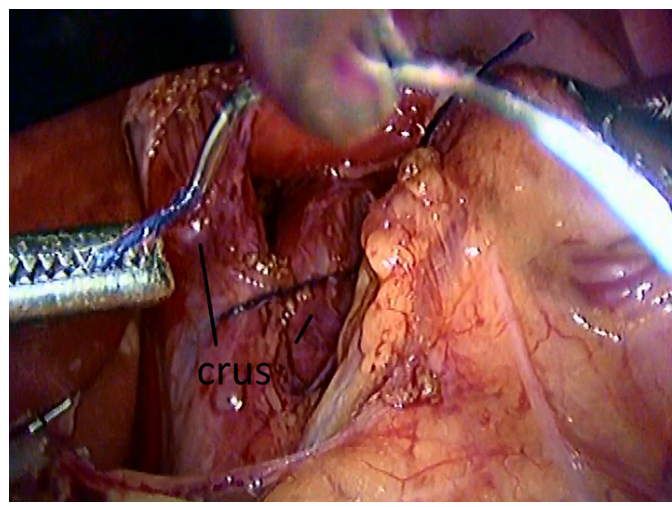

Figure 2: Hiatal closure must be performed with interrupted nonabsorbable X-shaped stitches (e.g. 2-0 or 0, polypropylene, mersilene). Stitches must be well anchored in the crus

effect with the lower esophageal sphincter at the esophagogastric junction, ${ }^{[29]}$ and prevents herniation of the wrap to the chest [Figure 2]. This type of herniation of the stomach (wrap) through the diaphragmatic hiatus is one of the main causes of failure after antireflux surgery. Some propose the use of prosthetic material (mesh) to reinforce the closure of the esophageal hiatus. The use of mesh for this purpose is still the subject of much discussion. ${ }^{[30]}$ While many believe that the use of this material can reduce the failure rates of the hiatal closing, ${ }^{[31]}$ others oppose this practice due to the risks of erosion of abdominal viscera (especially esophageal and gastric). The indication for the hiatal mesh repair should be selective taking into account the tension during crural closure and weakness of hiatal tissue. ${ }^{[29,32]}$

The fundoplication should be floppy, short, tensionfree, and constructed with the fundus of the stomach around the esophagus. An extensive dissection of the posterior attachments of the gastric fundus and an ample retroesophageal window are essential to make a tension-free fundoplication. Short gastric vessels division may also help attain a floppy fundoplication,
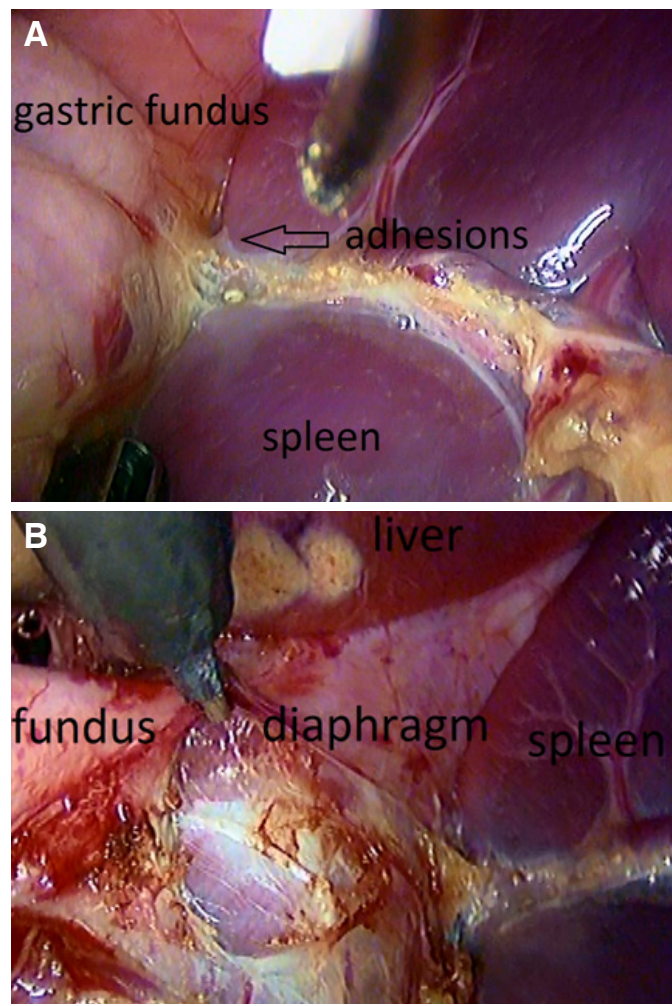

Figure 3: (A) A complete dissection of the gastric fundus ensures a tension-free fundoplication (arrow); (B) adhesiolysis of attachments of the gastric fundus to the spleen, diaphragm and retroperitoneum must be done even after division of the short gastric vessels

since it promotes the decrease of gastric fundus tension [Figure 3]. ${ }^{[33]}$

An intraluminal bougie is advocated by some to calibrate the fundoplication, ${ }^{[34]}$ although other different series do not show advantages. ${ }^{[35]}$ Another key step in this operation is the choice of the right place to create and position the wrap. Thus, gastro esophageal junction should be well identified, with the removal of the fat pad that is frequently located there. This is done to make sure that the gastric fundus is brought around the esophagus not the stomach. Also, the gastric fundus, not the gastric body should be used to create the fundoplication [Figure 4].

\section{FOLLOW-UP}

A good follow-up is important to achieve a satisfactory postoperative result. Patients who undergo this operation should be alerted about the common occurrence of transitory dysphagia in the first three months due to edema and esophageal ileus. ${ }^{[36]}$ Also, the improvement of extra esophageal symptoms may not be immediate and new symptoms, such as gas symptoms, may occur after surgery. These facts, however, do not decrease significantly quality of life and patient satisfaction with treatment. ${ }^{[5]}$ 
Table 2: Current results for laparoscopic Nissen fundoplication in adults in series over 100 patients in the last 5 years

\begin{tabular}{|c|c|c|c|c|c|}
\hline Author & $n$ & Follow-up & Outcomes & Morbidity & Mortality \\
\hline Andolfi et al. ${ }^{[6]}$ & 176 & 17 months & $88 \%$ symptom relieve & $\begin{array}{c}\text { Convertion rate } 0.6 \% \\
\text { Abdominal wall complications } 1.7 \%\end{array}$ & 0 \\
\hline van Rijn et al. ${ }^{[46]}$ & 125 & $14-25$ years & $62 \%$ satisfaction & NS & NS \\
\hline SarÄ et al. ${ }^{[47]}$ & 162 & 18 months & $\begin{array}{l}\quad 75 \% \text { symptom relieve } \\
9 \% \text { postoperative medication usage }\end{array}$ & NS & NS \\
\hline Warren et al. ${ }^{[48]}$ & 185 & $\begin{array}{l}\text { Minimum } 12 \\
\text { months }\end{array}$ & $\begin{array}{c}89 \% \text { satisfaction } \\
12 \% \text { postoperative medication } \\
\text { usage }\end{array}$ & $\begin{array}{c}2 \text { cases of abscess linked to mesh hiatoplasty } \\
1 \text { case of precocious revision due to } \\
\text { obstruction }\end{array}$ & 0 \\
\hline Koetje et al. ${ }^{[49]}$ & 329 & 24 months & $\begin{array}{l}\text { Significant improvements } \\
\text { in symptom score and QOL } \\
\text { measurements }\end{array}$ & Reoperation $7 \%$ & NS \\
\hline Teixeira et al. ${ }^{[50]}$ & 399 & 14 months & $98 \%$ symptom relieve & NS & NS \\
\hline Rossetti et al. ${ }^{[51]}$ & 301 & 56 months & Significant improvement in QOL & NS & NS \\
\hline Simorov et al. ${ }^{[52]}$ & 297 & 70 months & $\begin{array}{l}70 \% \text { improvement in GERD } \\
\text { symptoms }\end{array}$ & $\begin{array}{c}\text { Reoperation } 0.9 \% \\
5 \text { bleeding } \\
4 \text { pneumothoraces requiring decompression } \\
10 \text { wound infections } \\
3 \text { prolonged ileus } \\
8 \text { urinary retention }\end{array}$ & NS \\
\hline Kellokumpu et al. ${ }^{[53]}$ & 249 & 10 years & $\begin{array}{l}98 \% \text { symptom relieve } \\
83 \% \text { satisfaction }\end{array}$ & Morbidity $7.6 \%$ & 0 \\
\hline Qin et $a .^{[54]}$ & 215 & 5.6 years & $100 \%$ symptom relieve & NS & 0 \\
\hline Schietroma et al. ${ }^{[55]}$ & 178 & Minimum 11 years & $94 \%$ symptom relieve & Conversion rate $6 \%$ & 0 \\
\hline Beenen et al. ${ }^{[56]}$ & 222 & 11 years & $87 \%$ satisfaction & NS & NS \\
\hline Ross et al. ${ }^{[57]}$ & 510 & Minimum 10 years & $89 \%$ symptom relieve & NS & NS \\
\hline
\end{tabular}

NS: not stated; QOL: quality of life; GERD: gastroesophageal reflux disease

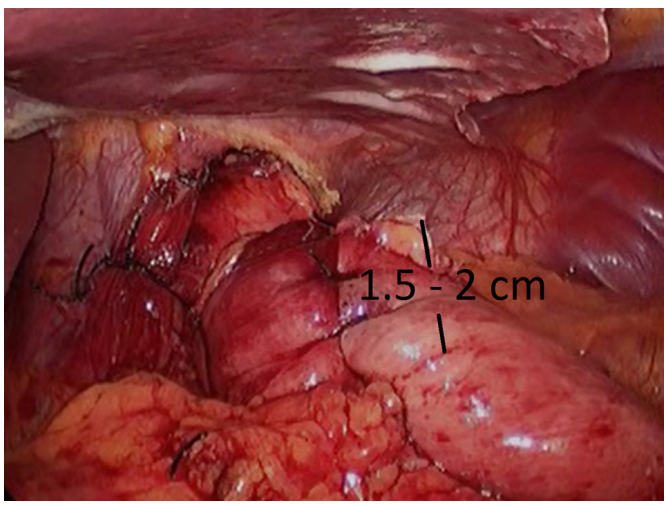

Figure 4: Fundoplication must be short-floppy and using gastric fundus only

\section{CONCLUSION}

New antireflux therapies are currently available. Novel acid suppressant drugs and other classes of medication are available or under development. ${ }^{[37]}$ However, up to now these medications have not shown clear advantages over current medication. Surgical therapy is aimed at the pathophysiology of the disease ${ }^{[38]}$ and can be more effective than current medical therapy. ${ }^{[39]}$ Surgical procedures other than a fundoplication; however, never gained acceptance for uncomplicated GERD cases. This is with the exception of bariatric procedures that control GERD and may be a good alternative to a fundoplication in obese individuals. ${ }^{[40]}$ Surgical technique has not changed expressively in the last several years; however, a
Nissen fundoplication may now be accomplished by endoscope. ${ }^{[41]}$ The technique is restricted to selected cases, lacks hiatal closure and results are inferior to a laparoscopic Nissen. Single port laparoscopy another option for performinga fundoplication; ${ }^{[42]}$ yet most believe it brings solely cosmetic improvement with a higher risk for complications. ${ }^{[43]}$ The aid of a robot in the operating room ${ }^{[44]}$ does not bring any advantage to the procedure and may add cost and time to the procedure. More recently, the fundoplication has been replaced by a magnetic chain of beads placed laparoscopically around the distal esophagus. ${ }^{[45]}$ Although good results are shown, the drawback of foreign material in the hiatus precludes dissemination of the technology.

Laparoscopic Nissen fundoplication continues to be safe and provides excellent outcomes [Table 2], not only in experienced hands, but also these results may be reproducible in community hospitals as well, ${ }^{[5,59]}$ if a proper preoperative workup, patient selection, surgical technique and follow-up are observed [Figure 5].

\section{Financial support and sponsorship}

Nil.

\section{Conflicts of interest}

There are no conflicts of interest.

\section{Patient consent}

There is no patient involved. 


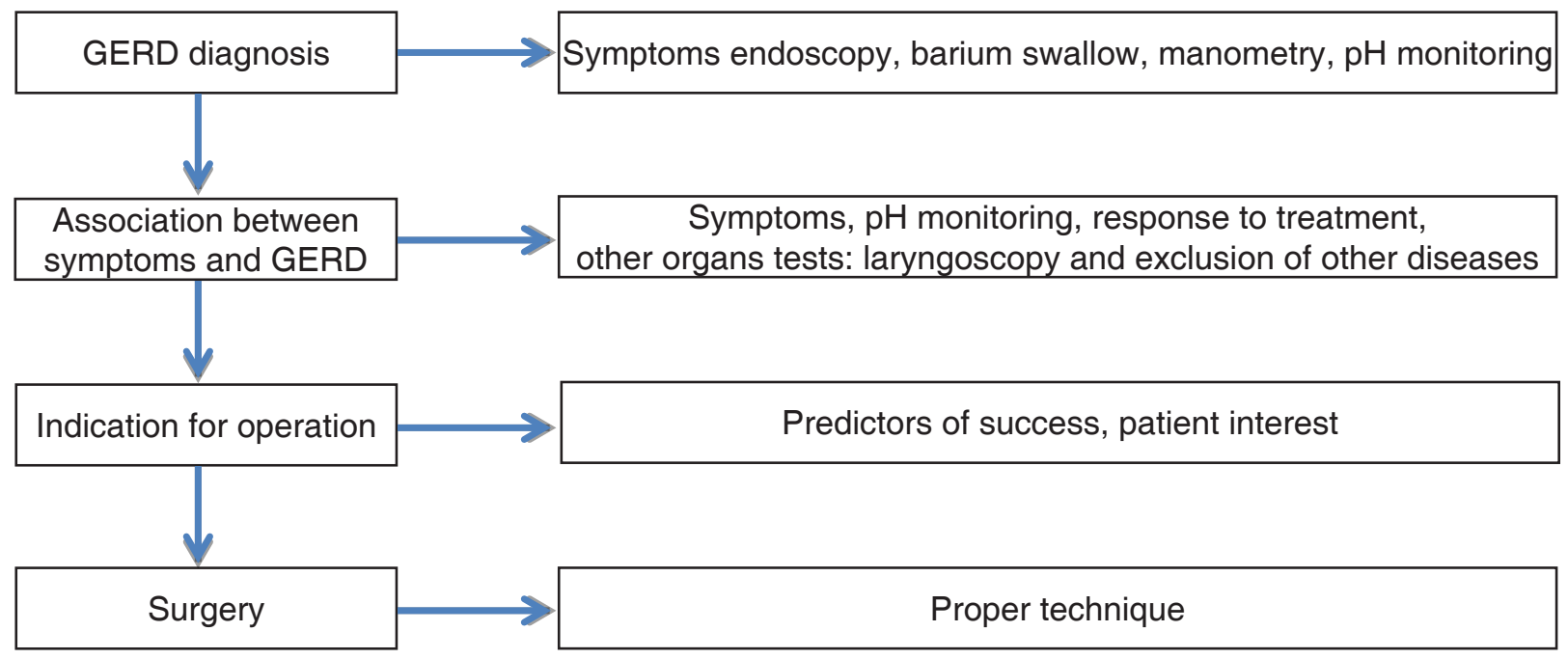

Figure 5: Road to a successful laparoscopic Nissen fundoplication. GERD: gastroesophageal reflux disease

\section{Ethics approval}

This review article is waived for ethical approval.

\section{REFERENCES}

1. Morgenthal CB, Shane MD, Stival A, Gletsu N, Milam G, Swafford V, Hunter JG, Smith CD. The durability of laparoscopic Nissen fundoplication: 11-year outcomes. J Gastrointest Surg 2007;11:693700 .

2. Eubanks TR, Omelanczuk P, Richards C, Pohl D, Pellegrini CA. Outcomes of laparoscopic antireflux procederes. Am J Surg 2000;179:391-5.

3. Peters JH, DeMeester TR, Crookes P, Oberg S, de Vos Shoop M, Hagen JA, Bremner CG. The treatment of gastroesophageal reflux disease with laparoscopic Nissen fundoplication: prospective evaluation of 100 patients with "typical" symptoms. Ann Surg 1998;228:40-50.

4. Dallemagne B, Weerts J, Markiewicz S, Dewandre JM, Wahlen C, Monami B, Jehaes C. Clinical results of laparoscopic fundoplication at ten years after surgery. Surg Endosc 2006;20:159-65.

5. Armijo PR, Herbella FAM, Patti MG. Surgical treatment of gastroesophageal reflux disease. A review of concepts that misguide indication for surgery. J Minim Invasive Surg Sci 2016;5:e33995.

6. Andolfi C, Vigneswaran Y, Kavitt RT, Herbella FA, Patti MG. Laparoscopic antireflux surgery: importance of patient's selection and preoperative workup. J Laparoendosc Adv Surg Tech A 2016; Epub ahead of print.

7. Patti MG, Arcerito M, Feo CV, De Pinto M, Tong J, Gantert W, Tyrrell D, Way LW. An analysis of operations for gastroesophageal reflux disease: identifying the important technical elements. Arch Surg 1998; 133:600-6

8. Laurino Neto RM, Herbella FA. Principles of Successful Surgical AntiReflux Procedures. In: Fisichella PM, editor. Managing Failed AntiReflux Therapy. London: Springer London; 2006. p. 57-65.

9. Jobe BA, Richter JE, Hoppo T, Peters JH, Bell R, Dengler WC, DeVault K, Fass R, Gyawali CP, Kahrilas PJ, Lacy BE, Pandolfino JE, Patti MG, Swanstrom LL, Kurian AA, Vela MF, Vaezi M, DeMeester TR. Preoperative diagnostic workup before antireflux surgery: an evidence and experience-based consensus of the Esophageal Diagnostic Advisory Panel. J Am Coll Surg 2013;217:586-97.

10. Bello B, Zoccali M, Gullo R, Allaix ME, Herbella FA, Gasparaitis A, Patti MG. Gastroesophageal reflux disease and antireflux surgery-what is the proper preoperative work-up? J Gastrointest Surg 2013;17:14-20.
11. Csendes A, Rencoret G, Beltran M, Smok G, Henriquez A. Relationship between gastroesophageal reflux symptoms and $24 \mathrm{~h}$ esophageal $\mathrm{pH}$ measurements in patients with normal or minimally abnormal upper endoscopies. Rev Med Chil 2004;132:19-25. (in Spanish)

12. Chan K, Liu G, Miller L, Ma C, Xu W, Schlachia CM, Darling G. Lack of correlation between a self-administered subjective GERD questionnaire and pathologic GERD diagnosed by esophageal $\mathrm{pH}$ monitoring. J Gastrointest Surg 2010;14:427-36.

13. Herbella FA, Andolfi C, Vigneswaran Y, Patti MG, Pinna BR. Importance of esophageal manometry and $\mathrm{pH}$ monitoring for the evaluation of otorhinolaryngologic (ENT) manifestations of GERD. A multicenter study. J Gastrointest Surg 2016;20:1673-8.

14. Gawron AJ, Hirano I. Advances in diagnostic testing for gastroesophageal reflux disease. World J Gastroenterol 2010;16:3750-6.

15. Herbella FA, Dubecz A. Extraesophageal Manifestation of Gastroesophageal Reflux Disease. In: Fisichella PM, Allaix ME, Morino M, Patti MG, editors. Esophageal Diseases. Evaluation and Treatment. Berlin: Springer; 2014. p. 95-108.

16. Kim D, Velanovich V. Surgical treatment of GERD: where have we been and where are we going? Gastroenterol Clin North Am 2014;43:135-45.

17. Patti MG, Allaix ME, Fisichella PM. Analysis of the causes of failed antireflux surgery and the principles of treatment: a review. JAMA Surg 2015;150:585-90.

18. Morgenthal CB, Lin E, Shane MD, Hunter JG, Smith CD. Who will fail laparoscopic Nissen fundoplication? Preoperative prediction of longterm outcomes. Surg Endosc 2007;21:1978-84.

19. O’Boyle CJ, Watson DI, DeBeaux AC, Jamieson GG. Preoperative prediction of long-term outcome following laparoscopic fundoplication. ANZ J Surg 2002;72:471-5.

20. Campos GM, Peters JH, DeMeester TR, Oberg S, Crookes PF, Tan S, DeMeester SR, Hagen JA, Bremner CG. Multivariate analysis of factors predicting outcome after laparoscopic Nissen fundoplication. $J$ Gastrointest Surg 1999;3:292-300.

21. Watson DI, Chan AS, Myers JC, Jamieson GG. Illness behavior influences the outcome of laparoscopic antireflux surgery. $\mathrm{J} \mathrm{Am} \mathrm{Coll}$ Surg 1997; 184:44-8.

22. Perez AR, Moncure AC, Rattner DW. Obesity adversely affects the outcome of antireflux operations. Surg Endosc 2001;15:986-9.

23. Tekin K, Toydemir T, Yerdel MA. Is laparoscopic antireflux surgery safe and effective in obese patients? Surg Endosc 2012;26:86-95.

24. Hahnloser D, Schumacher M, Cavin R, Cosendey B, Petropoulos P. Risk factors for complications of laparoscopic Nissen fundoplication. 
Surg Endosc 2002;16:43-7.

25. Tedesco P, Lobo E, Fisichella PM, Way LW, Patti MG. Laparoscopic fundoplication in elderly patients with gastroesophageal reflux disease. Arch Surg 2006;141:289-92.

26. Dell'Acqua-Cassão B, Mardiros-Herbella FA, Farah JF, Bonadiman A, Silva LC, Patti MG. Outcomes of laparoscopic Nissen fundoplication in patients with manometric patterns of esophageal motility disorders. Am Surg 2013;79:361-5.

27. DeMeester TR, Johnson LF. Position of the distal esophageal sphincter and its relationship to reflux. Surg Forum 1975;26:364-6.

28. Herbella FA, Del Grande JC, Colleoni R. Short esophagus or bad dissected esophagus? An experimental cadaveric study. J Gastrointest Surg 2003;7:721-5

29. Mittal RK, Rochester DF, McCallum RW. Sphincteric action of the diaphragm during a relaxed lower esophageal sphincter in humans. Am J Physiol 1989;256:G139-44.

30. Herbella FA, Patti MG, Del Grande JC. Hiatal mesh repair--current status. Surg Laparosc Endosc Percutan Tech 2011;21:61-6.

31. Granderath FA, Schweiger UM, Kamolz T, Pasiut M, Haas CF, Pointner R. Laparoscopic antireflux surgery with routine mesh-hiatoplasty in the treatment of gastroesophageal reflux disease. J Gastrointest Surg 2002;6:347-53.

32. Granderath FA, Schweiger UM, Pointner R. Laparoscopic antireflux surgery: tailoring the hiatal closure to the size of hiatal surface area. Surg Endosc 2007;21:542-8.

33. Szor DJ, Herbella FA, Bonini AL, Moreno DG, Del Grande JC. Gastric fundus tension before and after division of the short gastric vessels in a cadaveric model of fundoplication. Dis Esophagus 2009;22:539-42.

34. Jarral OA, Athanasiou T, Hanna GB, Zacharakis E. Is an intraoesophageal bougie of use during Nissen fundoplication? Interact Cardiovasc Thorac Surg 2012;14:828-33.

35. Somasekar K, Morris-Stiff G, Al-Madfai H, Barton K, Hassn A. Is a bougie required for the performance of the fundal wrap during laparoscopic Nissen fundoplication? Surg Endosc 2010;24:390-4.

36. Myers JC, Jamieson GG, Wayman J, King DR, Watson DI. Esophageal ileus following laparoscopic fundoplication. Dis Esophagus 2007;20:420-7.

37. Dutta U, Armstrong D. Novel pharmaceutical approaches to reflux disease. Gastroenterol Clin North Am 2013;42:93-117.

38. Herbella FA, Patti MG. Gastroesophageal reflux disease: from pathophysiology to treatment. World J Gastroenterol 2010;16:3745-9.

39. Rickenbacher N, Kötter T, Kochen MM, Scherer M, Blozik E. Fundoplication versus medical management of gastroesophageal reflux disease: systematic review and meta-analysis. Surg Endosc 2014;28:143-55.

40. Nadaleto BF, Herbella FA, Patti MG. Gastroesophageal reflux disease in the obese: pathophysiology and treatment. Surgery 2016;159:475-86.

41. Brar TS, Draganov PV, Yang D. Endoluminal therapy for gastroesophageal reflux disease: in between the pill and the knife? Dig Dis Sci 2016; Epub ahead of print.

42. Rosemurgy AS, Downs D, Swaid F, Ross SB. Laparoendoscopic single-site (LESS) Nissen fundoplication: how we do it. J Gastrointest Surg 2016;20:2093-9.

43. Volckmann ET, Hungness ES, Soper NJ, Swanstrom LL. Surgeon perceptions of Natural Orifice Translumenal Endoscopic Surgery (NOTES). J Gastrointest Surg 2009;13:1401-10.
44. Yao G, Liu K, Fan Y. Robotic Nissen fundoplication for gastroesophageal reflux disease: a meta-analysis of prospective randomized controlled trials. Surg Today 2014;44:1415-23.

45. Bonavina L, Saino G, Lipham JC, Demeester TR. LINX(®) Reflux Management System in chronic gastroesophageal reflux: a novel effective technology for restoring the natural barrier to reflux. Therap Adv Gastroenterol 2013;6:261-8

46. van Rijn S, Rinsma NF, van Herwaarden-Lindeboom MY, Ringers J, Gooszen HG, van Rijn PJ, Veenendaal RA, Conchillo JM, Bouvy ND, Masclee AA. Effect of vagus nerve integrity on short and long-term efficacy of antireflux surgery. Am J Gastroenterol 2016;111:508-15.

47. SarÄ A, Gonullu N, Tä Ryaki C, YazÄ cÄ Oglu M, Kargi E, Gonullu E, Yä Rmibesoglu A. Laparoscopic Nissen fundoplication: analysis of 162 patients. Int Surg 2016; Epub ahead of print.

48. Warren HF, Reynolds JL, Lipham JC, Zehetner J, Bildzukewicz NA Taiganides PA, Mickley J, Aye RW, Farivar AS, Louie BE. Multiinstitutional outcomes using magnetic sphincter augmentation versus Nissen fundoplication for chronic gastroesophageal reflux disease. Surg Endosc 2016;30:3289-96.

49. Koetje JH, Nieuwenhuijs VB, Irvine T, Mayne GC, Watson DI. Measuring outcomes of laparoscopic anti-reflux surgery: quality of life versus symptom scores? World J Surg 2016;40:1137-44.

50. Teixeira AC, Herbella FA, Bonadiman A, Farah JF, Del Grande JC Predictive factors for short gastric vessels division during laparoscopic total fundoplication. Rev Col Bras Cir 2015;42:154-8.

51. Rossetti G, Limongelli P, Cimmino M, Napoletano D, Bondanese MC, Romano G, Pratilas M, Guerriero L, Orlando F, Conzo G, Amato B, Docimo G, Tolone S, Brusciano L, Docimo L, Fei L. Outcome of medical and surgical therapy of GERD: predictive role of quality of life scores and instrumental evaluation. Int J Surg 2014;12 Suppl 1:S112-6.

52. Simorov A, Ranade A, Jones R, Tadaki C, Shostrom V, Boilesen E, Oleynikov D. Long-term patient outcomes after laparoscopic anti-reflux procedures. J Gastrointest Surg 2014;18:157-62.

53. Kellokumpu I, Voutilainen M, Haglund C, Färkkilä M, Roberts PJ, Kautiainen H. Quality of life following laparoscopic Nissen fundoplication: assessing short-term and long-term outcomes. World J Gastroenterol 2013;19:3810-8.

54. Qin M, Ding G, Yang H. A clinical comparison of laparoscopic Nissen and Toupet fundoplication for gastroesophageal reflux disease. $J$ Laparoendosc Adv Surg Tech A 2013;23:601-4.

55. Schietroma M, De Vita F, Carlei F, Leardi S, Pessia B, Sista F, Amicucci G. Laparoscopic floppy Nissen fundoplication: 11-year follow-up. Surg Laparosc Endosc Percutan Tech 2013;23:281-5.

56. Beenen E, Fogarty P, Roberts RH. Predicting patient dissatisfaction following laparoscopic Nissen fundoplication: an analysis of symptoms. Surg Endosc 2013;27:1579-86.

57. Ross SB, Gal S, Teta AF, Luberice K, Rosemurgy AS. Late results after laparoscopic fundoplication denote durable symptomatic relief of gastroesophageal reflux disease. Am J Surg 2013;206:47-51.

58. Neuvonen P, Iivonen M, Rantanen T. Endoscopic evaluation of laparoscopic nissen fundoplication: $89 \%$ success rate 10 years after surgery. World J Surg 2014;38:882-9.

59. Ranson ME, Danielson A, Maxwell JG, Harris JA. Prospective study of laparoscopic nissen fundoplication in a community hospital and its effect on typical, atypical, and nonspecific gastrointestinal symptoms. JSLS 2007;11:66-71. 